\title{
Katarzyna Maj-Waśniowska
}

Uniwersytet Ekonomiczny w Krakowie e-mail: katarzyna.maj@uek.krakow.pl

\section{NIESTABILNOŚCI WARUNKÓW FUNKCJONOWANIA SYSTEMU OŚWIATY W POLSCE}

\section{UNSTABLE CONDITIONS OF THE FUNCTIONING OF EDUCATIONAL SYSTEM IN POLAND}

DOI: $10.15611 /$ pn.2017.485.21

JEL Classification: H75, I21, I29

Streszczenie: W opracowaniu podjęta została problematyka niestabilności warunków funkcjonowania oświaty. Poruszony problem badawczy dotyczył w szczególności skali i kierunków zmian przepisów prawnych. W kontekście wdrażanej reformy systemu oświaty analizie poddano kierunki i charakter zmian w polityce edukacyjnej w Polsce od 1991 r. Struktura opracowania odzwierciedla przyjęte cele badawcze. W pierwszej kolejności omówione zostały uwarunkowania realizacji zadań oświatowych po transformacji ustrojowej. Następnie scharakteryzowano najważniejsze etapy kształtowania systemu oświaty oraz zakres i kierunki zmian w oparciu o analizę najważniejszych regulacji prawnych w tym obszarze. W toku przeprowadzonych analiz wykazano, że duża skala dokonywanych modyfikacji systemu oświaty, będąca efektem bardzo licznych nowelizacji ustaw, nie wynikała z realizacji spójnej długofalowej koncepcji rozwoju oświaty. W ostatniej części artykułu wskazano najważniejsze założenia nowej reformy systemu edukacji w Polsce oraz na podstawie analizy rozwiązań ustawowych jej skutki dla jednostek samorządu terytorialnego.

Słowa kluczowe: niestabilności systemu oświaty, reformy, zmiany przepisów prawa.

Summary: The author sheds light on the concept of unstable conditions, the functioning of the educational system. The research work further probes the general level of changes in the legal framework and its direction. An analysis of currently implemented policies and reforms with respect to the characteristics and policy direction of the educational system in Poland since 1991 have been studied and taken into account in this work. The paper indicates that the amount of modification and changes to the educational system and numerous amendments to the educational legal framework was not a result of implementing a long term coherent concept of educational development. The last part of the article indicates the main assumptions of new reform and its effects for local government units.

Keywords: unstability of education system, sreforms, amendment of legislation. 


\section{Wstęp}

Współcześnie edukacji przypisuje się fundamentalne znaczenie dla rozwoju społeczeństwa, wzrostu dobrobytu i konkurencyjności. Przemiany gospodarcze i społeczne wymuszają redefinicję polityki edukacyjnej zarówno jeżeli chodzi o jej podmioty, cele, jak i treści nauczania oraz adresatów. Adresatem tej polityki są obecnie wszyscy członkowie społeczeństwa - zarówno dzieci, młodzież, jak i dorośli, zgodnie z ujęciem edukacji jako spójnego systemu kształcenia i wychowania obejmującego różne poziomy kształcenia $\mathrm{w}$ formach instytucjonalnych i pozainstytucjonalnych [Ministerstwo Edukacji Narodowej i Sportu 2005, s. 26].

Zadania oświatowe wpisują się w katalog najistotniejszych zadań publicznych realizowanych przez państwo i jego organy. Polityka edukacyjna jest jednym z obszarów polityki państwa, które po transformacji ustrojowej podlegały zmianom (i w dalszym ciągu podlegają). Głównymi źródłami niestabilności warunków funkcjonowania oświaty są zarówno ciągłe zmiany przepisów prawa oświatowego, jak i zmiany demograficzne. Należy jednak zaznaczyć, że przyczyny tych niestabilności są różne. Zmiany przepisów prawa mają bowiem charakter endogeniczny i są zależne od organów państwa odpowiedzialnych za realizację polityki oświatowej. Demografia natomiast jest czynnikiem zewnętrznym, który wyznacza warunki realizacji zadań. Przepisy prawa mogą jedynie ograniczać negatywne skutki niżu demograficznego dla systemu oświaty. Mając na uwadze kluczowe znaczenie zmian regulacji prawnych w tym zakresie oraz charakter niniejszego opracowania, rozważania i analizy dotyczące niestabilności warunków realizacji zadań oświatowych ograniczono do zmian przepisów prawa.

Podstawową i specyficzną cechą wszystkich zmian zachodzących w tym obszarze jest długofalowy charakter występujących skutków, które w praktyce urzeczywistniają się w efekcie końcowym, czyli stopniu rozwoju społeczeństwa. W zależności od charakteru wprowadzanych zmian będą one nadawać społeczeństwu charakter mniej lub bardziej modernizacyjny czy innowacyjny. Reformy wdrażane w tym obszarze wynikają z wielu powodów. Z jednej strony są efektem konieczności dostosowania edukacji do współczesnych realiów życia społecznego-gospodarczego, ale równie często wynikają z realizacji doraźnych celów politycznych. Zmiany w systemie oświaty wprowadzane od $1991 \mathrm{r}$. dotykają wszystkich aspektów związanych z realizacją zadań w tym zakresie. Stąd też, mając na uwadze powyższe przesłanki, autorka podjęła problem badawczy, który został sformułowany w postaci pytań: Jaki jest zakres i charakter zmian legislacyjnych w obszarze polityki oświatowej? Czy wprowadzane zmiany były elementem spójnej koncepcji realizowanej w polityce edukacyjnej? Jakie są przesłanki nowej reformy edukacyjnej oraz jej skutki dla realizacji zadań oświatowych? Pochodnymi podjętego problemu badawczego są główne cele opracowania, do których należą: identyfikacja i charakterystyka kierunków oraz zakresu zmian przepisów prawnych regulujących funkcjonowanie systemu oświaty oraz analiza przyczyn i skutków wprowadzenia nowej reformy systemu edukacji. 
Struktura opracowania odzwierciedla przyjęte cele badawcze. W pierwszej kolejności przedstawiono uwarunkowania realizacji zadań oświatowych po transformacji ustrojowej. Następnie w sposób syntetyczny scharakteryzowane zostały zmiany w najważniejszych aktach prawnych w zakresie systemu oświaty. W ostatniej części artykułu przeprowadzono analizę regulacji prawnych w zakresie reformy edukacji z 2017 r. oraz wskazano skutki tych zmian dla jednostek samorządu terytorialnego. Całość opracowania kończy podsumowanie, w którym zawarto najistotniejsze wnioski płynące z badań.

\section{Uwarunkowania realizacji zadań oświatowych po 1989 roku}

Zarządzanie obszarem edukacji w Polsce wciąż determinowane jest skalą i zakresem urzeczywistniającego się w sferze prawa i praktyki procesu transformacji ustrojowej. Zasadnicze zmiany w konstrukcji systemu oświaty zainicjowano w 1991 r. Od tego momentu zaczął się proces przejmowania wciąż wówczas centralnie zarządzanych szkół przez samorządy terytorialne. Dopiero Konstytucja RP w 1997 r. [Konstytucja z 2 kwietnia 1997] powołała zasadę decentralizacji kompetencji państwa i zdefiniowała ustrojowe fundamenty działania samorządu terytorialnego jako podmiotu gwarantującego udział i wpływ obywatela na zadania publiczne. Zasada ta legła u podstaw obowiązującego obecnie modelu finansowania i zarządzania sferą oświaty. Stanowi ona obecnie docelowy model zarządzania obszarem publicznym. W 1999 r. zakończył się proces zarówno kształtowania administracyjnego podziału państwa, jak i przejmowania przez samorządy do realizacji zadań oświatowych jako zadań własnych. W kolejnym roku, czyli zaledwie 17 lat temu, edukacja stała się podmiotem bardzo głębokiej reformy, na którą składały się: reforma ustrojowa (wprowadzenie gimnazjów), reforma w zakresie statusu zawodowego nauczyciela (nowy system awansu zawodowego, nowy system wynagradzania) oraz reforma programowa.

Adresatem wprowadzanych reform i przemian stał się także samorząd. W efekcie wprowadzanych zmian nastąpiły głębokie przekształcenia w sposobie kształtowania jego zadań i dochodów. Zmiany systemowe, jak również jeden z podstawowych obszarów obowiązków publicznych państwa stały się przedmiotem sporów, które były (i są w dalszym ciągu) prowadzone na wielu płaszczyznach, w tym: społecznej, związanej z relacjami rząd/samorząd - nauczyciele, związki zawodowe, rodzice, stowarzyszenia itp., i de facto instytucjonalnej szkoła - samorząd - rząd). Były one przede wszystkim skutkiem przyspieszonej transformacji i związanego z tym zawężenia decentralizacji i transferu zadań do wyłącznie legislacyjnego działania, doraźnego wówczas charakteru podstawowych rozwiązań finansowych (ustawa o dochodach JST o dwu-, a potem trzyletnim okresie obowiązywania) czy obiektywizowania kryteriów redystrybucji dochodów kierowanych do znacznej liczby niejednolitych wówczas adresatów (JST) [Klawanek 2012, s. 4-5]. W konsekwencji wprowadzanych zmian i ich skutków u uczestników procesu pojawiło się często uzasadnione poczucie braku stabilności i nieadekwatności prowadzonych wobec siebie działań, 
a także konflikty pomiędzy podmiotami funkcjonującymi w jednolitym obszarze sfery publicznej (rząd/samorząd).

Ten pierwotny spór zdeterminował proces współdziałania w latach następnych i przejawiał się $\mathrm{w}$ tworzeniu licznych koncepcji i inicjatyw legislacyjnych oraz częstszym niż w innych obszarach kwestionowaniem istniejących lub wdrażanych rozwiązań systemowych na drodze postępowania przed Trybunałem Konstytucyjnym, a także protestami społecznymi itp. Jednocześnie na poziomie zarządzania samą szkołą nie doszło do przemian w sferze jej bieżącej organizacji (18-godzinny tydzień pracy, dodatki motywacyjne i niechęć do wykorzystywania kompetencji własnych w zakresie systemu płac) [Klawanek 2012, s. 4-5].

Urzeczywistnieniem tego sporu w praktyce były w kolejnych latach liczne zmiany regulacji ustawowych. Ponadto niekorzystne trendy demograficzne zachodzące w ostatnim okresie stały się przyczyną dodatkowych napięć towarzyszących realizacji zadań oświatowych. Jednostki samorządu terytorialnego (JST), początkowo starające się nie zauważać tego problemu, wraz z jego nasilaniem się zostały zmuszone do podjęcia określonej aktywności, zwykle związanej z koniecznością likwidacji placówek oświatowych. Stąd przyczyn problemów w obszarze funkcjonowania oświaty należy poszukiwać również na poziomie samorządu. Jednostki samorzą$\mathrm{du}$ terytorialnego często stosują uniwersalne rozwiązania, unikając podejmowania decyzji w zakresie podstawowych kwestii przekazanych do doprecyzowania na poziomie lokalnym. Ograniczenie korzystania przez JST z posiadanych kompetencji nieraz wynika właśnie z niestabilności przepisów prawa. Stąd wydaje się, że warunkiem skuteczności lokalnej polityki oświatowej jest zmiana podejścia do kreowania polityki oświatowej i zarządzania nią na szczeblu centralnym.

\section{Zakres zmian legislacyjnych determinujących ksztalt systemu oświaty}

Na przestrzeni lat 1989-2016 obraz polskiego systemu oświaty uległ zasadniczej zmianie. Reformy systemu oświaty opierały się na zmianach prawnych i administracyjnych. W ramach reformowania systemu oświaty można wyróżnić kilka zasadniczych etapów tego procesu.

Pierwszy z nich, od 1990 r., to tworzenie samodzielnego demokratycznie wybieranego samorządu gminnego, który przejął wiele zadań publicznych, w tym jedno z zakresu oświaty, tj. zadanie prowadzenia przedszkoli. Od 1993 r. gminy uzyskały ponadto prawo do przejmowania szkół podstawowych. Punktem wyjścia przy ustalaniu środków finansowych były historyczne koszty prowadzenia szkół podstawowych na terenie danej gminy. W późniejszym okresie przekazywanie (które de facto było wyposażeniem JST w wiele złożonych kompetencji) dokonywało się już tylko administracyjno-prawnie. Ponadto od 1 stycznia 1994 r. 43 spośród 46 miast o liczbie mieszkańców powyżej 100 tys., którym zaproponowano program pilotażowy, zaczęło go realizować [Rozporządzenie Rady Ministrów z 13 lipca 1993]. 
Jego wykonanie polegało na przejęciu od administracji rządowej do realizacji, na zasadzie zlecenia, zadań m.in. z zakresu oświaty i wychowania (prowadzenia szkół ponadpodstawowych, przedszkoli i szkół specjalnych). Zadania te przejęło 35 miast. Realizacja programu jednak się nie powiodła, głównie ze względu na system finansowania przejmowanych zadań.

Drugi etap obejmował lata 1996-1997 i był związany z obligatoryjnym przejmowaniem szkół podstawowych przez gminy (z wyjątkiem szkół specjalnych, artystycznych, przy zakładach karnych czy szpitalach). Procesowi temu towarzyszyła również zmiana sposobu finansowania zadań - w miejsce negocjowanych indywidualnie dotacji wprowadzono algorytm podziału części oświatowej subwencji ogólnej. Na mocy przepisów ustawy z dnia 22 grudnia 1995 r. o zmianie ustawy o finansowaniu gmin [Ustawa z 22 grudnia 1995] usunięto gwarancję zawartą w art. 20 ustawy [Ustawa z 10 grudnia 1993] (pełnego finansowania kosztów bieżących szkół przejętych przez gminy) i w jej miejsce wprowadzono systemowy mechanizm alokacji subwencji oświatowej dla wszystkich gmin. W ustawie określono, że łączna kwota subwencji oświatowej dla gmin nie może być niższa niż $6,6 \%$ dochodów budżetu państwa i musi być rozdzielona pomiędzy gminy na podstawie powszechnych i przejrzystych zasad, według algorytmu ustalanego przez MEN w uzgodnieniu ze stroną samorządową (art. 12a znowelizowanej ustawy). Ponadto wprowadzony algorytm, dzięki istnieniu progów ograniczających, gwarantował niezależnie od zmiany liczby uczniów kwotę subwencji na poziomie nie mniejszym niż w poprzednim roku. W ramach tego etapu w wyniku wejścia w życie 1 stycznia 1996 r. tzw. ustawy miejskiej [Ustawa z 24 listopada 1995] 46 miast, którym wcześniej zaproponowano realizację programu pilotażowego, obowiązkowo przejęło określone zadania własne, m.in. w dziedzinie oświaty i wychowania. Efektem wprowadzenia ustawy było przekazanie jednostkom samorządu terytorialnego 514 szkół zawodowych i techników, 401 liceów ogólnokształcących, 40 szkół artystycznych i 12 szkół medycznych [Kosek-Wojnar, Surówka 2007, s. 150].

Kolejny etap obejmował lata 1998-1999 i polegał na przekazaniu kompetencji zarządczych nad szkołami ponadgimnazjalnymi oraz większością pozaszkolnych zadań oświatowych nowo utworzonym samorządom powiatowym. W przeciwieństwie do gmin, które przejmowały zadania stopniowo, powiaty nie dysponowały sprawnie funkcjonującą strukturą organizacyjną i kadrami odpowiednimi do przekazywanych im zadań oświatowych. Ponadto sytuację utrudniało jednoczesne wejście w życie w 1999 r. reformy ustrojowej systemu oświaty związanej ze skróceniem czasu trwania nauki w szkole podstawowej z ośmiu do sześciu lat, wprowadzeniem trzyletniego szczebla gimnazjalnego oraz skróceniem nauki w szkole ponadgimnazjalnej (dawnej ponadpodstawowej).

Zakończenie procesu tworzenia systemu oświaty nastąpiło w 2000 r. Przyjęcie ostatecznego kształtu systemu było związane również ze zmianą w sposobie jego finansowania poprzez algorytm podziału części oświatowej subwencji ogólnej. Dwa dotychczasowe algorytmy (dla szkół podstawowych i gimnazjów oraz dla szkół po- 
nadpodstawowych funkcjonujący w 1999 r.) zostały zastąpiony jednym dla wszystkich typów szkół i szczebli samorządu, placówek oświatowych realizujących zarówno zadania szkolne, jak i pozaszkolne. Kształt algorytmu utworzonego w $2000 \mathrm{r}$. wynikał również z wprowadzenia nowego systemu awansu zawodowego nauczycieli, co znalazło odzwierciedlenie w formie dodatkowych wag (mnożników). Mechanizm ten funkcjonuje nieprzerwanie do $2017 \mathrm{r}$. Jednak podlegał on licznym zamianom i modyfikacjom.

Działania realizowane w systemie oświaty po $2000 \mathrm{r}$. związane były ze wzmacnianiem roli organów prowadzących i dotyczyły zmian w systemie zarządzania i finansowania oświaty. Polegały one przede wszystkim na ograniczeniu uprawnień organów nadzoru pedagogicznego, zwłaszcza w procesie reorganizacji sieci szkół. Ponadto organy prowadzące uzyskały większą autonomię w zakresie podejmowania decyzji dotyczących finansowania szkół. Bezpośrednia kontrola zarządcza sprawowana przez kuratoria została zastąpiona kontrolą prawną (przeprowadzaniem ewaluacji) sprawowaną przez kuratoria oświaty, kontrolą procesu budżetowego przez regionalne izby obrachunkowe oraz systemem monitorowania efektów pracy szkół (przez system egzaminów zewnętrznych od 2002 r.) [Herbst i in. 2015, s. 12].

Lata 1989-2016 to czas, kiedy obok sporów o charakterze ideologicznym i światopoglądowym, samorząd przejął odpowiedzialność za realizację zadań oświatowych, przeprowadzono trzy wielkie reformy edukacji, w tym jedną strukturalną, kilkadziesiąt zmian programowych i organizacyjnych, obniżono wiek rozpoczęcia realizacji obowiązku szkolnego do 6. roku życia, po czym ponownie go podniesiono do 7 lat. Niewątpliwie duże znaczenia z punktu widzenia funkcjonowania systemu oświaty miało również uchwalenie ustawy z dnia 19 lutego 2004 r. o systemie informacji oświatowej (SIO) [Ustawa z 19 lutego 2004], związanej z usprawnieniem procesu zarządzania w oświacie. System ten wprowadził nową jakość w zakresie gromadzenia danych statystycznych w dziedzinie oświaty. Od 2011 r. obowiązuje jednak nowa ustawa w tym zakresie, której funkcjonowanie w praktyce $\mathrm{w}$ dalszym ciągu związane jest $\mathrm{z}$ licznymi problemami przy naliczaniu subwencji [Ustawa z 15 kwietnia 2011].

Należy jednak zaznaczyć, że od 2015 r. wprowadzano zmiany, które miały na celu ponowne wzmocnienie roli kuratora oświaty i tym samym ograniczenie kompetencji organów prowadzących. Ponadto 1 września 2017 r. wejdzie w życie ustawa Prawo oświatowe [Ustawa z 14 grudnia 2016], która oznacza kolejną reformę ustroju szkolnego. Rozwiązania w niej zawarte oznaczają przywrócenie systemu szkolnego zbliżonego do tego sprzed reformy z 1999 r. Bilans najważniejszych zmian w systemie oświaty przedstawia tabela 1 .

Zmiany systemu oświaty w Polsce dokonujące się na przestrzeni wielu lat wymuszały dokonywanie istotnych zmian w przepisach prawnych. Aby zilustrować skalę tych zmian, wystarczy wspomnieć, że dwa kluczowe dla funkcjonowania systemu oświaty akty prawne, tj. ustawa z dnia 7 września 1991 r. o systemie oświaty [Ustawa z dnia 7 września 1991] i ustawa - Karta Nauczyciela [Ustawa z dnia 26 stycznia 1982], były zmieniane kilkadziesiąt razy. W przypadku pierwszego z nich zmian tych było ponad 150 (w tym $4 \times$ tekst jednolity), a druga $\mathrm{z}$ ustaw zmieniana była 90 razy 
Tabela 1. Bilans zmian w systemie oświaty w Polsce w latach 1989-2017

\begin{tabular}{|l|l|l|}
\hline \multicolumn{1}{|c|}{1989} & \multicolumn{1}{|c|}{2015} & \multicolumn{1}{|c|}{2017} \\
\hline $\begin{array}{l}\text { Prawo 6-latków do } \\
\text { przygotowania przedszkolnego }\end{array}$ & $\begin{array}{l}\text { Obowiązek rocznego } \\
\text { przygotowania przedszkolnego } \\
\text { dla dzieci 5-letnich }\end{array}$ & $\begin{array}{l}\text { Obowiązek rocznego } \\
\text { przygotowania przedszkolnego } \\
\text { dla dzieci 6-letnich }\end{array}$ \\
\hline $\begin{array}{l}\text { Obowiązek szkolny dla dzieci } \\
\text { 7-letnich }\end{array}$ & $\begin{array}{l}\text { Obowiązek szkolny dla dzieci } \\
\text { 6-letnich }\end{array}$ & $\begin{array}{l}\text { Obowiązek szkolny dla dzieci } \\
\text { 7-letnich }\end{array}$ \\
\hline $\begin{array}{l}\text { 8-letnia szkoła podstawowa, } \\
\text { szkoły ponadpodstawowe }\end{array}$ & $\begin{array}{l}\text { 6-letnia szkoła podstawowa, } \\
\text { 3-letnie gimnazja, 3(4)-letnie } \\
\text { szkoły ponadgimnazjalne }\end{array}$ & $\begin{array}{l}\text { 8-letnia szkoła podstawowa, } \\
\text { szkoły ponadpodstawowe* }\end{array}$ \\
\hline $\begin{array}{l}\text { Jednolite obowiązujące } \\
\text { programy nauczania } \\
\text { i podręczniki }\end{array}$ & $\begin{array}{l}\text { Obowiązująca podstawa } \\
\text { programowa i wielość } \\
\text { programów, w tym własnych, } \\
\text { oraz wielość podręczników } \\
\text { do wyboru; ramowe plany } \\
\text { nauczania określają minimalną } \\
\text { liczbę godzin na danym etapie } \\
\text { edukacyjnym }\end{array}$ & $\begin{array}{l}\text { Obowiązujące różne podstawy } \\
\text { programowe oraz ramowe plany } \\
\text { nauczania w zależności od etapu } \\
\text { edukacyjnego, } \\
\text { ramowe plany nauczania } \\
\text { określają tygodniowy wymiar } \\
\text { godzin z danego przedmiotu }\end{array}$ \\
\hline $\begin{array}{l}\text { Jeden organ prowadzący } \\
\text { szkoły i sprawujący nadzór } \\
\text { pedagogiczny }\end{array}$ & $\begin{array}{l}\text { Rozdział funkcji nadzoru } \\
\text { pedagogicznego od funkcji } \\
\text { organu prowadzącego, nowy } \\
\text { nadzór pedagogiczny }\end{array}$ & $\begin{array}{l}\text { Rozdział funkcji nadzoru } \\
\text { pedagogicznego od funkcji } \\
\text { organu prowadzącego, ponowne } \\
\text { wzmocnienie roli nadzoru } \\
\text { pedagogicznego }\end{array}$ \\
\hline $\begin{array}{l}\text { System egzaminów } \\
\text { wewnętrznych w szkołach } \\
\text { ponadpodstawowych }\end{array}$ & $\begin{array}{l}\text { System egzaminów } \\
\text { zewnętrznych }\end{array}$ & $\begin{array}{l}\text { System egzaminów } \\
\text { zewnętrznych }\end{array}$ \\
\hline $\begin{array}{l}\text { Brak systemu finansowania } \\
\text { zadań oświatowych }\end{array}$ & $\begin{array}{l}\text { System subwencji oświatowej } \\
\text { dla samorządów i dotacji dla } \\
\text { szkolnictwa niepublicznego }\end{array}$ & $\begin{array}{l}\text { System subwencji oświatowej } \\
\text { dla samorządów i dotacji dla } \\
\text { szkolnictwa niepublicznego }\end{array}$ \\
\hline Nieliczne szkoły niepubliczne & $\begin{array}{l}\text { Bogata oferta szkolnictwa } \\
\text { niepublicznego }\end{array}$ & $\begin{array}{l}\text { Bogata oferta szkolnictwa } \\
\text { niepublicznego }\end{array}$ \\
\hline Szkoła samorządowa & Szkoła samorządowa \\
\hline
\end{tabular}

* Struktura szkolnictwa w zakresie szkół ponadpodstawowych będzie obejmowała: liceum ogólnokształcące, technikum, branżową szkołę I stopnia, szkołę specjalną przysposabiającą do pracy, branżową szkołę II stopnia, szkołę policealną.

Źródło: opracowanie własne na podstawie [Ustawa z 7 września 1991; Ustawa z 14 grudnia 2016a].

(w tym 5× tekst jednolity). Tylko w latach 2000-2005, a zatem w latach wdrażania reformy systemowej, ustawę tę zmieniano ponad 20 razy. Wyjątkową sytuacją stał się przypadek, w którym ustawę - Karta Nauczyciela zmieniano codziennie, jak np. w dniu 23 i 24 sierpnia 2001 r., przy czym kolejna ustawa zmieniała niektóre rozstrzygnięcia przyjęte dzień wcześniej. Wprowadzane zmiany wynikały zarówno z nowelizacji tych dwóch aktów prawnych, jak i licznych zmian w innych ustawach, które 
bezpośrednio skutkowały zmianami w omawianych aktach prawnych. Liczbę zmian w najważniejszych ustawach regulujących system oświaty przedstawia tabela 2.

Tabela 2. Liczba zmian w najważniejszych aktach prawnych regulujących funkcjonowanie systemu oświaty w Polsce w latach 1991-2018

\begin{tabular}{|c|c|c|c|}
\hline ROK & $\begin{array}{l}\text { Ustawa z dnia } 7 \text { września } \\
1991 \text { r. o systemie oświaty }\end{array}$ & $\begin{array}{l}\text { Ustawa z dnia } 26 \text { stycznia } \\
1982 \text { r. - Karta Nauczyciela }\end{array}$ & $\begin{array}{l}\text { Ustawa o systemie } \\
\text { informacji oświatowej }\end{array}$ \\
\hline 1 & 2 & 3 & 4 \\
\hline 1990 & - & $\begin{array}{l}\text { liczba zmian w latach } \\
1982-1990-11\end{array}$ & - \\
\hline 1991 & 1 & 2 & - \\
\hline 1992 & 2 & 3 & - \\
\hline 1993 & 2 & 1 & - \\
\hline 1994 & 2 & 4 & - \\
\hline 1995 & 0 & 0 & - \\
\hline \multirow[t]{2}{*}{1996} & 2 & \multirow[t]{2}{*}{3} & \multirow[t]{2}{*}{-} \\
\hline & $\begin{array}{l}\text { ogłoszenie tekstu } \\
\text { jednolitego, Dz.U. 1996, } \\
\text { nr } 67 \text {, poz. } 329\end{array}$ & & \\
\hline \multirow[t]{2}{*}{1997} & \multirow[t]{2}{*}{1} & 2 & \multirow[t]{2}{*}{-} \\
\hline & & $\begin{array}{l}\text { ogłoszenie tekstu jednolitego, } \\
\text { Dz.U. } 1997, \text { nr } 56 \text {, poz. } 357\end{array}$ & \\
\hline 1998 & 0 & 0 & - \\
\hline 1999 & 5 & 2 & - \\
\hline 2000 & 4 & 4 & - \\
\hline 2001 & 7 & 3 & - \\
\hline 2002 & 6 & 3 & - \\
\hline \multirow[t]{2}{*}{2003} & & 2 & \multirow{2}{*}{$\begin{array}{l}\text { zgłoszenie projektu - druk } \\
\text { sejmowy nr } 1708 \text { (Sejm IV } \\
\text { kadencji) }\end{array}$} \\
\hline & 4 & $\begin{array}{l}\text { ogłoszenie tekstu jednolitego, } \\
\text { Dz.U. 2003, nr 118, poz. } \\
1112\end{array}$ & \\
\hline \multirow[t]{2}{*}{2004} & 9 & \multirow[t]{2}{*}{6} & 19 lutego - uchwalenie ustawy \\
\hline & $\begin{array}{l}\text { ogłoszenie tekstu } \\
\text { jednolitego, Dz.U. 2004, nr } \\
256 \text {, poz. } 2572\end{array}$ & & $\begin{array}{l}26 \text { marca ogłoszenie ustawy, } \\
\text { Dz.U. 2004, nr 49, poz. } 463\end{array}$ \\
\hline \multirow[t]{2}{*}{2005} & \multirow[t]{2}{*}{10} & \multirow[t]{2}{*}{5} & 1 stycznia - wejście w życie \\
\hline & & & 1 \\
\hline \multirow[t]{2}{*}{2006} & \multirow[t]{2}{*}{3} & 1 & \multirow[b]{2}{*}{-} \\
\hline & & $\begin{array}{l}\text { ogłoszenie tekstu jednolitego, } \\
\text { Dz.U. 2006, nr 97, poz. } 674\end{array}$ & \\
\hline
\end{tabular}


Tabela 2, cd.

\begin{tabular}{|c|c|c|c|}
\hline 1 & 2 & 3 & 4 \\
\hline 2007 & 8 & 7 & 1 \\
\hline 2008 & 6 & 2 & - \\
\hline 2009 & 6 & 10 & - \\
\hline 2010 & 8 & 1 & $\begin{array}{l}\text { zgłoszenie projektu - druk } \\
\text { sejmowy nr } 3628 \text { (Sejm VI } \\
\text { kadencji) }\end{array}$ \\
\hline \multirow[t]{2}{*}{2011} & \multirow[t]{2}{*}{5} & \multirow[t]{2}{*}{0} & $\begin{array}{l}15 \text { kwietnia - uchwalenie } \\
\text { ustawy }\end{array}$ \\
\hline & & & $\begin{array}{l}5 \text { lipca ogłoszenie ustawy } \\
\text { i częściowe wejście w życie } \\
\text { w zakresie art. } 128, \text { ust. } 1, \\
\text { Dz.U. } 2011, \text { nr } 139, \text { poz. } 814\end{array}$ \\
\hline \multirow[t]{3}{*}{2012} & \multirow[t]{3}{*}{5} & \multirow[t]{3}{*}{3} & $\begin{array}{l}30 \text { kwietnia - uchylenie } \\
\text { ustawy z dnia } 19 \text { lutego } 2004 \text { r. } \\
\text { oraz wejście w życie ustawy } \\
\text { z dnia } 15 \text { kwietnia } 2004 \mathrm{r} \text {. }\end{array}$ \\
\hline & & & $\begin{array}{l}1 \text { sierpnia - częściowe wejście } \\
\text { w życie w zakresie art. } 102, \\
103,121\end{array}$ \\
\hline & & & 2 \\
\hline 2013 & 4 & 2 & 1 \\
\hline \multirow[t]{2}{*}{2014} & \multirow[t]{2}{*}{17} & $\begin{array}{l}\text { ogłoszenie tekstu jednolitego, } \\
\text { Dz.U. 2014, nr } 191\end{array}$ & \multirow[t]{2}{*}{3} \\
\hline & & 1 & \\
\hline \multirow[t]{2}{*}{2015} & 14 & \multirow[t]{2}{*}{1} & 4 \\
\hline & $\begin{array}{l}\text { ogłoszenie tekstu } \\
\text { jednolitego Dz.U. 2015, } \\
\text { poz. } 2156\end{array}$ & & $\begin{array}{l}\text { ogłoszenie tekstu jednolitego, } \\
\text { Dz.U. 2015, poz. } 45\end{array}$ \\
\hline \multirow[t]{2}{*}{2016} & 18 & 6 & 4 \\
\hline & $\begin{array}{l}\text { ogłoszenie tekstu } \\
\text { jednolitego, Dz.U. 2016, } \\
\text { poz. } 1943\end{array}$ & $\begin{array}{l}\text { ogłoszenie tekstu jednolitego, } \\
\text { Dz.U. 2016, poz. } 1379\end{array}$ & $\begin{array}{l}\text { ogłoszenie tekstu jednolitego, } \\
\text { Dz.U. 2016, poz. } 1927\end{array}$ \\
\hline $2017^{a}$ & 6 & 5 & 3 \\
\hline Razem & $\begin{array}{l}155 \text { zmian } \\
4 \text { teksty jednolite ustawy }\end{array}$ & $\begin{array}{l}90 \text { zmian } \\
5 \text { tekstów jednolitych ustawy }\end{array}$ & $\begin{array}{l}\text { od } 2011 \text { r. }-17 \text { zmian } \\
2 \text { teksty jednolite ustawy }\end{array}$ \\
\hline
\end{tabular}

a - wejście w życie 1 września ustawy z 14 grudnia 2016 r. - Prawo oświatowe, Dz.U. 2017, poz. 59, oraz ustawy z 14 grudnia 2016 r. - Przepisy wprowadzające ustawę - Prawo oświatowe, Dz.U. 2017, poz. 60

Źródło: opracowanie własne na podstawie [https://sip.lex.pl/\#/akt/16794386/2150591/system-oswiaty; https://sip.lex.pl/\#/akt/16790821/2150564/karta-nauczyciela; https://sip.lex.pl/\#/akt/17717090/ 2132127/system-informacji-oswiatowej]. 


\section{Reforma systemu edukacji w Polsce - kierunki zmian}

Obowiązująca od 1991 r. ustawa o systemie oświaty była jedną z najczęściej nowelizowanych ustaw. Liczne, a przy tym obszerne nowelizacje, wprowadzające obok zmian w samej ustawie wiele regulacji epizodycznych i przejściowych, spowodowały brak przejrzystości i tym samym czytelności tego podstawowego dla funkcjonowania oświaty polskiej aktu prawnego. Nowa ustawa - Prawo oświatowe [Ustawa z 14 grudnia 2016a] obejmuje swoim zakresem przedmiotowym część materii regulowanej dotychczas przez ustawę o systemie oświaty i stanowi podstawę do wprowadzania dwóch odrębnych ustaw dotyczących finansowania oświaty oraz sposobu oceniania osiągnięć uczniów, w tym systemu ich egzaminowania. Ustawa ta wraz $\mathrm{z}$ ustawą Przepisy wprowadzające ustawę - Prawo oświatowe [Ustawa z 14 grudnia 2016b] (nowelizującą m.in. ustawę z 7 września 1991 r. o systemie oświaty oraz ustawę z 26 stycznia 1982 r. - Karta Nauczyciela) oznacza zasadnicze zmiany w organizacji oświaty w Polsce. Najważniejszą zmianą w stosunku do obowiązującego stanu prawnego są rozwiązania dotyczące nowego ustroju szkolnego oraz związane z tym modyfikacje w organizacji i funkcjonowaniu szkół i placówek oświatowych. Przewiduje się także zmiany systemowe w wybranych obszarach oświaty, wzmacniające i uzupełniające zmiany ustroju szkolnego. W ramach nowych rozwiązań przewidziano m.in.:

- wzmocnienie roli szkoły w budowaniu kompetencji do funkcjonowania we współczesnym świecie poprzez kształtowanie postaw prospołecznych oraz otwartości na innowacyjność,

- wydłużenie nauki w szkole podstawowej do ośmiu lat i likwidację gimnazjów,

- zmiany w szkolnictwie zawodowym poprzez wprowadzenie nowych typów szkół ponadpodstawowych prowadzących kształcenie w zawodach oraz wprowadzenie nowych poziomów wykształcenia (zasadniczego branżowego oraz średniego branżowego),

- ograniczenie w przekazywaniu przez jednostki samorządu terytorialnego szkół do prowadzenia osobie prawnej niebędącej JST oraz osobie fizycznej (brak możliwości przekazania ostatniej szkoły prowadzonej przez daną JST),

- zmiany w organizacji nadzoru pedagogicznego i wzmocnienie jego pozycji w zakresie dotyczącym poleceń wydawanych dyrektorom szkół i placówek oraz organom prowadzącym $\mathrm{w}$ sprawie usunięcia uchybień polegających na prowadzeniu działalności niezgodnej z prawem,

- zmiany w zakresie rekrutacji do publicznych przedszkoli i innych form wychowania przedszkolnego oraz publicznych szkół i placówek,

- przeniesienie na poziom ustawy - Prawo oświatowe regulacji, które dotychczas znajdowały się w rozporządzeniu w sprawie Ramowych statutów przedszkoli i szkół publicznych m.in. dotyczących: treści, które szkoła musi uregulować w swoim statucie, organizacji pracy świetlicy, jak również tworzenia stanowisk kierowniczych w szkołach. 
Wśród przyczyn wprowadzania nowych rozwiązań wymienia się m.in. te związane z problemami funkcjonowania gimnazjów i szkolnictwa ponadgimnazjalnego. W przypadku gimnazjów dotyczy to w szczególności zróżnicowania wyników egzaminu gimnazjalnego pomiędzy szkołami. Mimo iż w Polsce nastąpiła znaczna poprawa wyników osiąganych przez uczniów na tym poziomie kształcenia i zmniejszyły się różnice wynikające $\mathrm{z}$ pochodzenia społecznego, to jednak towarzyszył temu wzrost różnic wewnątrz szkół. Można więc stwierdzić, że jest to sprzeczne z założeniami reformy z 1999 r., zgodnie z którymi obwodowe gimnazja miały służyć wyrównywaniu szans edukacyjnych. Ponadto istotnym wyzwaniem towarzyszącym realizacji zadań oświatowych $\mathrm{w}$ zakresie prowadzenia gimnazjów jest również niż demograficzny. Liczba uczniów gimnazjów w pierwszych latach ich funkcjonowania (2000-2005) wzrosła o ponad 34\% i od tego roku systematycznie spada, zmniejszając się o około 33\% w roku szkolnym 2016/17. Natomiast liczba szkół w analogicznym okresie wzrosła o blisko 20\% [GUS 2016]. Spadkowi liczby uczniów towarzyszyło zwiększanie się liczby tych placówek, co prowadziło do coraz większych trudności w finansowaniu gimnazjów. W związku z postępującym spadkiem liczby uczniów w ostatnich latach wiele gmin decydowało się na łączenie tych placówek w zespoły szkół podstawowych i gimnazjów, co jednak było również niezgodne z założeniami reformy z 1999 r. - tworzenia gimnazjów jako samodzielnych szkół.

W zakresie szkolnictwa ponadgimnazjalnego w przypadku liceów zmiany wynikają z nieefektywnej organizacji nauki w tych szkołach. W zasadzie czas właściwej nauki uległ skróceniu do dwóch lat, a koncentracja godzin na wybranych 2-4 przedmiotach rozszerzonych spowodowała, iż utraciło ono charakter szkoły ogólnokształcącej. Natomiast szkoły zawodowe, zwłaszcza zasadnicze, mimo działań prowadzonych od 2012 r. mających na celu przywrócenie atrakcyjności tej formy kształcenia, w dalszym ciągu są rzadko wybierane, a stopa bezrobocia wśród absolwentów tych szkół jest najwyższa ('średnio wynosi powyżej 40\%).

System kształcenia zawodowego i sposób realizacji zadań w tym obszarze są uwarunkowane zmianami otoczenia społeczno-gospodarczego związanymi m.in. $\mathrm{z}$ budową gospodarki opartej na wiedzy, globalizacją procesów gospodarczych, mobilnością zawodową, nowymi technologiami, a także wzrostem oczekiwań pracodawców w zakresie poziomu wiedzy i umiejętności pracowników. Stąd miarą efektywności tego systemu kształcenia powinno być dostosowanie go do potrzeb rynku pracy. Nowo tworzone szkoły branżowe (I i II stopnia) mają przygotować absolwentów nie tylko do podjęcia pracy zawodowej, ale umożliwiają również kontynuowanie nauki w szkole II stopnia oraz dalsze podnoszenie kwalifikacji (obecna szkoła zawodowa nie daje możliwości, po jej ukończeniu, uzyskania dyplomu technika).

Istota nowej reformy sprowadza się do stworzenia spójnej i kompleksowej struktury organizacji szkół oraz wydłużenia okresu kształcenia i wychowania w jednej szkole. Świadczy o tym zmiana ramowych planów nauczania. Dotychczas na ich podstawie tworzone były szkolne plany nauczania dające swobodę dyrektorom 
szkół w zakresie realizacji nauczania obowiązkowych przedmiotów na danym etapie nauczania. Nowe regulacje w tym zakresie poszerzyły upoważnienie ustawowe ministra właściwego do spraw oświaty i wychowania o możliwości wydania rozporządzenia określającego wytyczne oraz tygodniowy wymiar godzin obowiązkowych zajęć edukacyjnych. Oznacza to ujednolicenie nauczania przedmiotów w ramach poszczególnych typów szkół. Powyższe wskazuje, że podstawowym celem reformy, w kontekście zachodzących zmian demograficznych, jest wprowadzenie cykliczności etapów szkolnych, któremu towarzyszyć będą zmiany programowe mające na celu dostosowanie szkoły do realiów funkcjonowania w nowej rzeczywistości społeczno-gospodarczej.

Niezależnie od zmian w zakresie fundamentalnych rozwiązań związanych z funkcjonowaniem oświaty, nie sposób nie dostrzec konsekwencji tych zmian dla jednostek samorządu terytorialnego, czyli organów prowadzących szkoły. Samorządy są odpowiedzialne za wdrożenie nowych regulacji prawnych i to przed nimi stoją największe wyzwania w tym zakresie. Zadanie to wydaje się tym trudniejsze, że realizowane jest niejako wbrew nim. Zdaniem samorządowców likwidacja gimnazjów (w formule tzw. wygaszania) spowoduje zaprzepaszczenie wysiłku organów prowadzących ten rodzaj szkół. Od ich utworzenia w 1999 r. samorządy wydały na ich funkcjonowanie (w cenach bieżących) łącznie 130 miliardów złotych, w tym 8 miliardów na inwestycje. Ponadto także inne podmioty prowadzące gimnazja w całej Polsce (przede wszystkim organizacje obywatelskie i kościoły) wydatkowały na ten cel kilkanaście miliardów złotych. Wygaszanie gimnazjów spowoduje dodatkowe koszty szacowane $\mathrm{w}$ gminach na kwotę ponad 1 miliarda złotych, a także trudne do oszacowania koszty pośrednie likwidacji gimnazjów, które dotkną nie tylko samorządy. Nieuniknionym skutkiem reformy systemu edukacji w zapowiedzianym kształcie będzie także zredukowanie wielu obecnych, małych szkół 6-klasowych do funkcji 4-klasowych szkół filialnych. Oznaczać to będzie dodatkowe dowożenie dzieci, a w konsekwencji pogorszenie warunków nauczania i niezadowolenie rodziców [Związek Miast Polskich 2016]. Kolejnym negatywnym skutkiem wdrażanej reformy może okazać się redukcja zatrudnienia nauczycieli. Organy prowadzące szkoły wskazują również na inne potencjalne skutki wdrażanej reformy, dotyczące w szczególności obniżenia poziomu kształcenia, a w konsekwencji jakości pracy szkoły, będących wynikiem nasilonej migracji nauczycieli gimnazjów oraz realizacji przez nich zajęć edukacyjnych w kilku szkołach w okresie transformacji ustroju szkolnego. JST wskazują też na nietrafność diagnozy będącej podstawą wprowadzanych zmian i poszukiwanie niedoskonałości systemu oświaty w jego kształcie i ustroju, a nie w programach nauczania. Ponadto mimo tak dużej skali zmian nie przedstawiono równolegle nowych rozwiązań w zakresie finansowania oświaty, co faktycznie uniemożliwia organom JST określenie rzeczywistych skutków dla ich budżetów [Związek Gmin Wiejskich RP 2016].

Ponadto analiza rozwiązań prawnych zawartych w ustawie - Prawo oświatowe pozwala stwierdzić, że przepisy te oznaczają ograniczenie w pewnych obsza- 
rach swobody realizacji zadań oświatowych przez JST. Ograniczenia te widoczne są w największym stopniu w sferze organizacji i zarządzania oświatą na szczeblu lokalnym. Dotyczy to w szczególności przepisów ustawy, które uzależniają decyzje gmin dotyczące sieci szkół od zgody kuratora. W konsekwencji następuje przeniesienie decyzji na organ, który nie ponosi żadnej odpowiedzialności, w tym finansowej, za realizację zadań dotyczących prowadzenia szkół. Podobne ograniczenie kompetencji JST ma miejscu w przypadku przekazywania szkół do prowadzenia innym podmiotom oraz likwidacji szkół i placówek oświatowych. Towarzyszy temu również zwiększenie kompetencji organu nadzoru pedagogicznego. Znaczenie kuratorów zwiększy się także w zakresie procedury związanej z arkuszami organizacji pracy szkół, których zatwierdzenie przez organ prowadzący wymagać będzie uzyskania opinii organu nadzoru pedagogicznego. Ograniczenia nastąpią też w organizacji przez dyrektora pracy szkoły w zakresie zasad przydzielania godzin zajęć ponadnormatywnych dla nauczycieli oraz ich zatrudniania. W okresie do 31 sierpnia 2023 r. dyrektor szkoły prowadzonej przez JST musi informować kuratora oświaty sprawującego nadzór pedagogiczny nad szkołą o wolnych stanowiskach pracy dla nauczycieli. Informacje te udostępniane będą na stronie podmiotowej kuratorium oświaty.

Powyższe wskazuje, że największe kontrowersje towarzyszą nie samej reformie, ale przede wszystkim sposobowi jej wdrażania. Zmiany systemu edukacji w tej skali powinny cieszyć się szeroką społeczną aprobatą i mieć charakter ewolucyjny. Powinny być również gruntownie przygotowane i szeroko konsultowane, a także wprowadzane w czasie umożliwiającym bardzo dobre przygotowanie elementów składowych tych zmian.

\section{Zakończenie}

Na przestrzeni 17 lat od $2000 \mathrm{r}$. najpierw powołano fundamentalną reformę systemową, a następnie na poziomie działań organizacyjnych i niewielkich zmian legislacyjnych - skutecznie ją ograniczono. Kluczowe zmiany systemu wprowadzono w stosunkowo krótkim, z punktu widzenia etapu rozwojowego ucznia, okresie. Pospieszne i niekonsekwentne zmiany dokonywały się poprzez ingerencję w obszar uzależniony od zupełnie innego cyklu, podporządkowanego innym procesom (szczeble kształcenia i wychowania, doskonalenia zawodowego nauczycieli) [Klawanek 2012, s. 6]. Część zmian systemowych w tym przypadku zawsze przynosi konsekwencje nieodwracalne. Należy podkreślić, iż 17 lat po wejściu w życie gruntownej reformy systemu edukacji po raz kolejny zmianie ulega jego ustrój i struktura. Współczesna teoria zarządzania obszarem i zasady, które powinny być podstawą dokonywania zmian, wskazują, iż w żadnym przypadku dynamiczny i trwający proces nie może być weryfikowany na poziomie niezależnym od zobiektywizowanej oceny skutku. W szczególności powinno to dotyczyć kształcenia, które jest procesem długofalowym wymagającym ciągłości i stabilności [Klawanek 2012, s. 7]. 
W kontekście postawionego we wstępie problemu badawczego najważniejszym wnioskiem płynącym z badań jest stwierdzenie, że nieodłącznym elementem realizacji polityki oświatowej są zmiany, które wprowadzane są na mocy kolejnych nowelizacji ustaw, nawet kilka razy w ciągu roku. Zdarzają się sytuacje, że zmieniane są przepisy, które jeszcze nie zaczęły obowiązywać. Nie sposób w tym miejscu dokonać oceny kolejnych wprowadzonych rozwiązań, bowiem praktyka prac legislacyjnych towarzyszących projektom aktów prawnych pokazuje, że właściwie każda ze stron tych prac, a szczególnie na etapie konsultacji społecznych, wskazuje ułomności projektowanych propozycji. Mimo iż uwagi i oczekiwania partnerów społecznych są niekiedy uwzględniane, to jednak często są on przejawem patrzenia poszczególnych grup na projektowane rozwiązania przez pryzmat ich celów. Tym samym można stwierdzić, że kolejne zmiany często realizowane są z pominięciem analizy ich skutków dla najważniejszych podmiotów w procesie edukacji, czyli uczniów.

Przeprowadzana analiza charakteru i zakresu zmian przepisów regulujących funkcjonowanie oświaty wskazuje, że wiele $\mathrm{z}$ wprowadzonych w procesie kształtowania systemu edukacji rozwiązań miało pozytywne skutki w postaci modernizacji systemu oświaty i dostosowania go do zmieniającego się otoczenia. Mimo że wzrasta rola budowania dhugofalowych strategii, to jednak brak konsekwencji w ich realizacji oraz w dalszym ciągu stosunkowo duża podatność na zmiany polityczne osłabiają skuteczność realizacji celów polityki oświatowej. W konsekwencji postulaty i wyzwania postawione przed polską oświatą wiele lat temu pozostają w dalszym ciągu aktualne. Jako przykład można tutaj przywołać dokument opracowany przez Instytut Spraw Publicznych [2005] pt. „Najważniejsze wyzwania stojące przed polską oświatą". Zawarto w nim trzy rekomendacje, które w dużym stopniu pozostają aktualne do dziś. Pierwsza z nich mówi, że Polska potrzebuje długofalowej i konsekwentnie realizowanej strategii rozwoju oświaty. Druga zwraca uwagę, aby reformy programowe szły w parze z ewolucją szkoły w stronę instytucji autonomicznej i demokratycznej. Natomiast trzecia akcentuje potrzebę skuteczniejszego łączenia przez system oświaty zadań podtrzymywania spójności społecznej i tworzenia potencjału modernizacji kraju. Warto również zaznaczyć, że wprowadzana w 2017 r. reforma edukacji również ma na celu realizację tych postulatów.

W rezultacie należy stwierdzić, że sama potrzeba wprowadzenia zmian w systemie edukacji nie jest kwestionowana, ale powinna ona być rezultatem uwzględniania zweryfikowanych przesłanek wynikających z monitorowania stopnia realizacji założonych celów lub celów zmodyfikowanych. Szczególna rola, jaką pełni system oświaty, powoduje, że zmiany, które ingerują w trwający proces kształcenia, powinny być wprowadzane $\mathrm{z}$ wyprzedzeniem uwzględniającym etapy kształcenia, zasady finansowania i przygotowanie merytoryczne i formalne podmiotów, których dotyczą.

$\mathrm{Na}$ zakończenie warto zauważyć, że przeprowadzone analizy mogą stanowić podstawę do dalszych badań obejmujących poruszaną problematykę. Do szczególnie interesujących należy m.in. analiza związku wprowadzanych rozwiązań z postę- 
pującymi zmianami demograficznymi, która umożliwiłaby odpowiedź na pytanie, na ile zmiany w systemie oświaty podyktowane są świadomością potrzeby redefinicji polityki oświatowej realizowanej w warunkach niżu demograficznego. Ciekawe wydaje się również zagadnienie analizy zmian mechanizmu finansowania zadań oświatowych na tle wprowadzanych reform i zmian demograficznych.

\section{Literatura}

GUS, 2016, Oświata $i$ wychowanie w roku szkolnym 2015/2016, Warszawa.

Herbst M., Herczyński J., Federowicz M., Smak M., Walczak D., Wojciuk A., 2015, Bilans zmian instytucjonalnych. Polska oświata w okresie transformacji, Instytut Badań Edukacyjnych, Warszawa.

https://sip.lex.pl/\#/akt/16794386/2150591/system-oswiaty.

https://sip.lex.pl/\#/akt/16790821/2150564/karta-nauczyciela.

https://sip.lex.pl/\#/akt/17717090/2132127/system-informacji-oswiatowej.

Instytut Spraw Publicznych, 2005, Najważniejsze wyzwania stojące przed polska oświata, Analizy i Opinie, nr 45, s. 1-7.

Klawanek A., 2012, Analiza lokalnych regulaminów płacowych nauczycieli, Interdyscyplinarne Centrum Modelowania Matematycznego i Komputerowego, Uniwersytet Warszawski, Warszawa.

Konstytucja Rzeczypospolitej Polskiej z dnia 2 kwietnia 1997 r., Dz.U. 1997, nr 78, poz. 483 ze zm.

Kosek-Wojnar M., Surówka K., 2007, Podstawy finansów samorządu terytorialnego, Wydawnictwo Naukowe PWN, Warszawa.

Ministerstwo Edukacji Narodowej i Sportu, 2005, Strategia Rozwoju Edukacji na lata 2007-2013, Warszawa.

Rozporządzenie Rady Ministrów z 13 lipca 1993 r. w sprawie określenia zadań i kompetencji z zakresu rządowej administracji ogólnej i specjalnej, które mogą być przekazane niektórym gminom o statusie miasta, wraz z mieniem służącym do ich wykonywania, a także zasad i trybu przekazania, Dz.U. nr 65, poz. 309.

Ustawa z 7 września 1991 r. o systemie oświaty, Dz.U. nr 95, poz. 425 ze zm.

Ustawa z 10 grudnia 1993 r. o finansowaniu gmin, Dz.U. nr 129, poz. 600 ze zm.

Ustawa z 14 grudnia 2016 r. (a) - Prawo oświatowe, Dz.U. 2017, poz. 59.

Ustawa z 14 grudnia 2016 r. (b) - Przepisy wprowadzające ustawę - Prawo oświatowe, Dz.U. 2017, poz. 60 .

Ustawa z 15 kwietnia 2011 r. o systemie informacji oświatowej, Dz.U. nr 139, poz. 814 ze zm.

Ustawa z 19 lutego 2004 r. o systemie informacji oświatowej, Dz.U. nr 49, poz. 463 ze zm.

Ustawa z 22 grudnia 1995 r. o zmianie ustawy o finansowaniu gmin, Dz.U. nr 154, poz. 794.

Ustawa z 24 listopada 1995 r. o zmianie zakresu działania niektórych miast oraz o miejskich strefach usług publicznych, Dz.U. nr 141, poz. 692.

Ustawa z 26 stycznia 1982 r. - Karta Nauczyciela, Dz.U. nr 3, poz. 19 ze zm.

Związek Gmin Wiejskich RP, 2016, Stanowisko Związku Gmin Wiejskich Rzeczypospolitej Polskiej w sprawie projektowanych przez Ministra Edukacji Narodowej zmian w systemie oświaty (projekt ustawy „Prawo oświatowe” z dnia 16.09.2016 r. oraz projekt ustawy „Przepisy wprowadzające ustawę - Prawo oświatowe z dnia 16.09.2016 roku), http://debata.edu.pl/attachments/article/15/ Stanowisko_ZGWRP_proj_ustaw_Prawo_oswiatowe_i_wprowadzenie.pdf (01.05.2017).

Związek Miast Polskich, 2016, Stanowisko Związku Miast Polskich w sprawie planowanych przez resort edukacji narodowej zmian w systemie oświaty, http://miasta.socialidea.pl/uploads/document/ content_file/312/Stanowisko_ZMP_ws._planowanych_zmian_w_o_wiacie.pdf (01.05.2017). 